\title{
Characterization of Insulin Receptors in Patients with the Syndromes of Insulin Resistance and Acanthosis Nigricans
}

\author{
R. S. Bar ${ }^{1}$, M. Muggeo, C. R. Kahn, Ph. Gorden, and J. Roth \\ ${ }^{1}$ Division of Endocrinology, University of Iowa, Iowa City, Iowa, and Diabetes Branch, NIH, Bethesda, Maryland, USA
}

\begin{abstract}
Summary. This report analyzes the in vitro characteristics of ${ }^{125} \mathrm{I}$-insulin binding to the monocytes of nine patients with the syndromes of acanthosis nigricans and insulin resistance. The 3 Type A patients (without demonstrable autoantibodies to the insulin receptor) had decreased binding of insulin due to a decreased concentration of receptors. In these patients the residual receptors demonstrated normal dissociation kinetics, negative cooperativity, and were blocked by anti-receptor antibodies in a manner similar to normal cells. In contrast, monocytes from the 6 Type B patients (with circulating anti-receptor autoantibodies) had decreased binding of insulin due to a decrease in receptor affinity. Insulin binding to monocytes of Type B patients demonstrated accelerated rates of dissociation with no evidence of cooperative interactions among insulin receptors. When coupled with previous data, the present studies further suggest that different mechanisms account for the defects in insulin binding and insulin resistance observed in these patients.
\end{abstract}

Key words: Insulin receptors, acanthosis nigricans, insulin resistance, insulin receptor autoantibodies, Type A patients, Type B patients, negative cooperativity.

Several patients with acanthosis nigricans and an extreme form of insulin resistance have now been described [1-4]. These patients can be divided into two groups: Type A patients, who are younger females with signs of excess androgenic effects and Type B patients, who are older and have signs of autoimmune disease. Patients in both groups show severe defects in insulin-receptor binding and Type B patients have circulating antibodies which impair insulin receptor function. The clinical course in some of these patients $[5,6]$ and a detailed description and characterization of the autoantibodies to the insulin receptor have been reported previously [7-15].

In the present study we have analyzed in greater detail the interaction of insulin with its receptor on the circulating monocytes of nine patients with these syndromes ( 3 Type A and 6 Type B) in order to elucidate further the pathogenesis of these syndromes.

\section{Materials and Methods}

\section{Patients}

Clinical data are summarized for the nine patients in Table 1. Detailed clinical descriptions of patients A-1 [3], A-3 [3], B-1 [3], B-2 [3], B-3 [3], B-4 [16] and B-6 [14] have already been published. Patients A-4 and B-5 have not been previously reported. All patients had low or undetectable levels of anti-insulin antibodies. Prior to the binding studies, patient B- 6 had received no insulin therapy for 7 days whereas the other patients had received no insulin therapy for at least 14 days. Insulin binding studies in patient A-2 are not reported here since initial binding data were not complete enough to allow detailed evaluation. It is also important to emphasize that all studies shown in this report for Type B patients were performed during initial presentation to the National Institutes of Health, since both binding characteristics and clinical course have been shown to vary in followup studies $[5,6]$. Informed consent was obtained from all patients prior to study.

\section{Insulin Binding}

a. Competition Studies. Studies of insulin binding to circulating monocytes were performed as previously described $[17,18]$. Briefly, crystalline porcine insulin was labeled with ${ }^{125} \mathrm{I}$ at a specific activity of $130-200 / \mu \mathrm{Ci} / \mu \mathrm{g}$ insulin $[19,20](0.4-0.6 \mathrm{I}$ atoms per insulin molecule). Tracer amounts of ${ }^{125} \mathrm{I}$-insulin $(0.2 \mathrm{ng} / \mathrm{ml})$ were incubated with $20 \times 10^{6}$ mononuclear cells and varying concentrations of unlabelled insulin in a final volume of $0.5 \mathrm{ml}$. After $3 \mathrm{~h}$ 
Table 1. Clinical features in patients with insulin resistance and acanthosis nigricans ${ }^{\mathrm{a}}$

\begin{tabular}{|c|c|c|c|c|c|c|c|c|c|}
\hline $\begin{array}{l}\text { Patient } \\
\text { designation }\end{array}$ & Sex & Age & Race & $\begin{array}{l}\text { Abnormality in } \\
\text { glucose tolerance } \\
\text { test }\end{array}$ & $\begin{array}{l}\text { Acanthosis } \\
\text { nigricans }\end{array}$ & $\begin{array}{l}\text { Tendency to } \\
\text { ketosis }\end{array}$ & $\begin{array}{l}\text { Basal } \\
\text { insulin } \\
\mu \mathrm{U} / \mathrm{ml}\end{array}$ & $\begin{array}{l}\text { Maximal insulin } \\
\text { therapy dose to } \\
\text { which patient } \\
\text { was resistant }\end{array}$ & $\begin{array}{l}\text { Anti-R } \\
\text { titre }^{c}\end{array}$ \\
\hline A-1 & $\mathrm{F}$ & 16 & Black & Moderate & Moderate & Yes & $180-220$ & $48,000 \mathrm{U} /$ day & N. D. \\
\hline A-3 & $\mathrm{F}$ & 13 & White & Mild (normal FBG) & Moderate & No & 300 & ITT $0.2 \mathrm{U} / \mathrm{kg}$ & N. D. \\
\hline$A-4$ & $\mathrm{~F}$ & 18 & White & Mild (normal FBG) & Mild & No & $80-130$ & ITT $0.2 \mathrm{U} / \mathrm{kg}$ & N. D. \\
\hline B-1 & $\mathrm{F}$ & 36 & Creole & Mild (normal FBG) & Moderate & No & $80-228$ & ITT $0.1 \mathrm{U} / \mathrm{kg}$ & $1: 3$ \\
\hline$B-2$ & $\mathrm{~F}$ & 38 & Black & Severe & Severe & Yes & - & $6,000 \mathrm{U} / \mathrm{day}$ & $1: 2000$ \\
\hline B-3 & $\mathrm{F}$ & 48 & Black & Severe & Moderate & No & 120 & $24,000 \mathrm{U} /$ day & $1: 80$ \\
\hline$B-4$ & $\mathrm{~F}$ & 62 & Black & Severe & None & No & - & 2,250 U/day & $1: 300$ \\
\hline B-5 & M & 62 & Black & Severe & Severe & Yes & - & $3,000 \mathrm{U} / \mathrm{day}$ & $1: 2000$ \\
\hline B-6 & $\mathrm{F}$ & 40 & Black & Severe & Severe & Yes & - & $10,000 \mathrm{U} / \mathrm{day}$ & $1: 80$ \\
\hline
\end{tabular}

Abbreviations: $M=$ male, $F=$ female, $F B G=$ fasting blood glucose, $I T T=$ insulin tolerance test, $N$. D. = not detectable

a Adapted from reference 10 , with permission

b Age at time of study

c Antireceptor antibody (Anti-R) titres are the dilutions of serum which inhibited ${ }^{125}$ I-insulin binding to IM-9 lymphoblastoid cells by $50 \%$

at $22^{\circ} \mathrm{C}, 200 \mu \mathrm{l}$ samples were removed, layered onto $100 \mu \mathrm{l}$ of cold buffer (Hepes $100 \mathrm{mmol} / \mathrm{l} \mathrm{pH} 8.0,4{ }^{\circ} \mathrm{C}$ ) in $400 \mu / \mathrm{l}$ tubes and centrifuged in a Beckman microfuge for 1 minute at $8700 \mathrm{~g}$. The supernatant was removed, and the cell pellet counted. Nonspecific binding, defined as the amount of ${ }^{125} \mathrm{I}$-insulin bound in the presence of $10^{5} \mathrm{ng} / \mathrm{ml}$ insulin, was substracted from total binding to yield specific binding. Nonspecific binding ranged from $0.3-1.1 \%$ in both normal subjects and patients. Degradation of ${ }^{125} \mathrm{I}$-insulin was always less then $15 \%$ (by trichloracetic acid precipitation) in both patient and control studies. Binding data are expressed as specific binding $/ 4.8 \times 10^{6}$ monocytes; the proportion of monocytes in the mononuclear cell preparation was determined by phagocytosis of latex beads and ranged from $18-30 \%$ with no consistent difference among patients or between patient and control subjects [21]. The results of the binding studies were similar whether data were expressed per $20 \times 10^{6}$ mononuclear cells or per $4.8 \times 10^{6}$ monocytes. The binding data are expressed as competition-inhibition curves, Scatchard plots [22] and average affinity profiles [23]. The competition-inhibition curves represent the actual experimental data whereas Scatchard plots and affinity profiles allow quantitation of receptor concentration and receptor affinity, respectively. More detailed descriptions of these three methods of data presentation have been reported previously [22, 23].

b. Cooperativity Experiments. For the cooperativity experiments the patient's mononuclear cells were first incubated with $0.2 \mathrm{ng} / \mathrm{ml}$ of ${ }^{125} \mathrm{I}$-porcine insulin for $180 \mathrm{~min}$ at $22^{\circ} \mathrm{C}$ in Hepes buffer $(\mathrm{pH}$ 8.0). Aliquots, $100 \mu \mathrm{l}$, of the incubation mixture were then added to $10 \mathrm{ml}$ of buffer ("dilution only") and to buffer plus $10^{-7} \mathrm{~mol} / \mathrm{I}$ unlabelled porcine insulin ("dilution + unlabelled insulin") and maintained at $15^{\circ}$ or $22^{\circ} \mathrm{C}$. At $0 \mathrm{~min}, 30 \mathrm{~min}$, and $60 \mathrm{~min}$, the tubes were centrifuged at $1000 \mathrm{~g}$ for $3 \mathrm{~min}$, the supernatant was aspirated and discarded, and the radioactivity in the cell pellet was counted. At each time point, $\%{ }^{125} \mathrm{I}$-insulin in the pellet (receptorbound) was then expressed as \% receptor-bound insulin at time 0 [24].

c. Effect of Antireceptor Antibodies. To demonstrate the effect of Type B sera (containing anti-receptor antibodies) on monocyte receptors, the patient's monocytes and monocytes from normal subjects were first exposed to Type B serum for $2 \mathrm{~h}$ at $22^{\circ} \mathrm{C}$, washed extensively in serum-free buffer and then incubated with

${ }^{125} \mathrm{I}$-insulin for measurement of specific insulin binding [2].

\section{Results}

\section{Type A Patients}

The monocytes of all Type A patients showed a marked decrease in the binding of ${ }^{125} \mathrm{I}$-insulin. With tracer concentration $(0.2 \mathrm{ng} / \mathrm{ml})$ binding ranged from $20 \%$ of the normal mean in patient A-1 to $60 \%$ of normal in patient A-4 (Fig. 1). For each patient, \% decrease in binding was generally uniform over the entire range of insulin concentrations.

Scatchard plots were curvilinear with upward concavity, which is typical of all insulin receptors (Fig. 1, center). Fifty-percent inhibition of maximal binding was achieved with insulin concentrations of $5-10 \mathrm{ng} / \mathrm{ml}$ in the three type A patients (normal range $1.2-12 \mathrm{ng} / \mathrm{ml}$ ) indicating that receptor affinity was unchanged. The lack of affinity change is further emphasized by the average affinity profiles (Fig. 1, right). At all levels of receptor occupancy the average affinity profiles were within normal limits in the Type A patients.

Cooperativity Studies. Insulin receptors of two of the three Type A patients (A-1, A-4), were evaluated for cooperative interactions (Fig. 2). In both patients, the dissociation rate was accelerated in the presence of $10^{-7} \mathrm{~mol} / \mathrm{l}$ insulin, consistent with the finding of receptor site-site interactions of the negatively cooperative type. 
COMPETITION CURVE

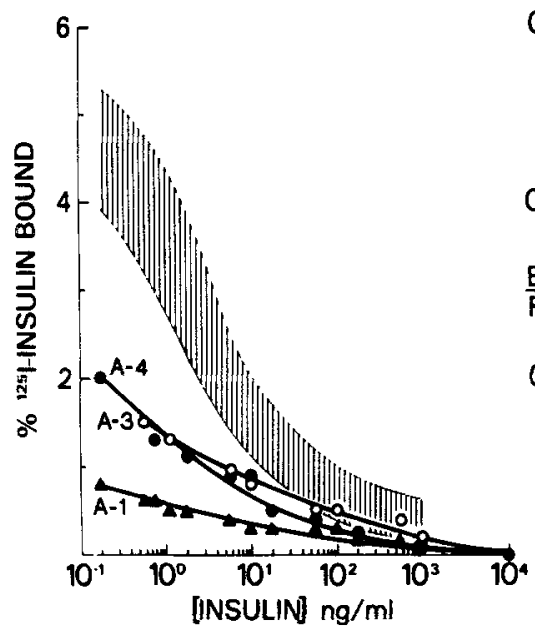

SCATCHARD PLOT

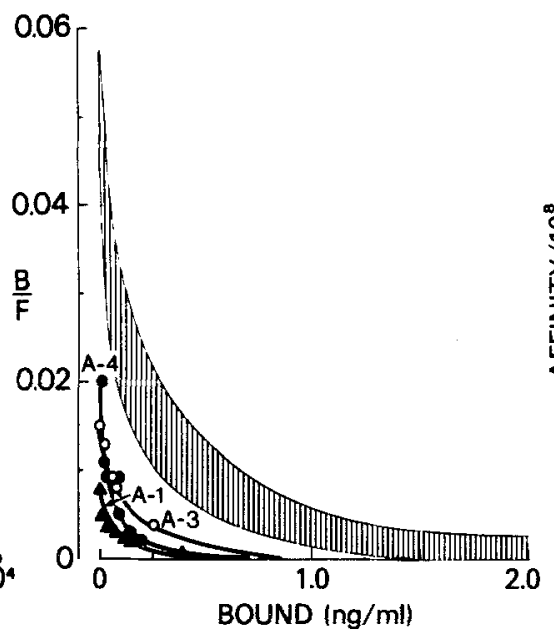

AFFINITY PROFILE

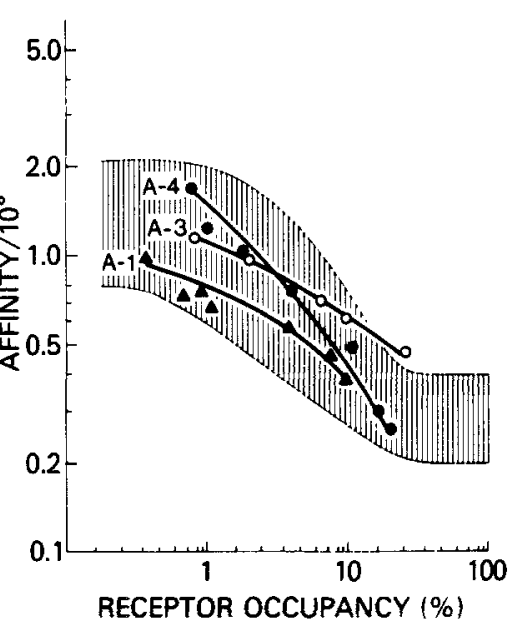

Fig. 1. ${ }^{125} \mathrm{I}$-insulin binding to monocytes of patients A-1, A-3 and A-4. Competition-inhibition curves (\% ${ }^{125} \mathrm{I}$-insulin specifically bound vs. insulin concentration) are at the left, Scatchard plots (bound/free hormone vs bound hormone) in the middle and average affinity profile (average affinity vs \% receptor occupancy) at the right. The hatched areas represent the mean \pm 1 SD for the competition-inhibition curves and the range of normal for the Scatchard plots and average affinity profiles. All binding data in this figure and subsequent figures are expressed per $4.8 \times 10^{6}$ monocytes
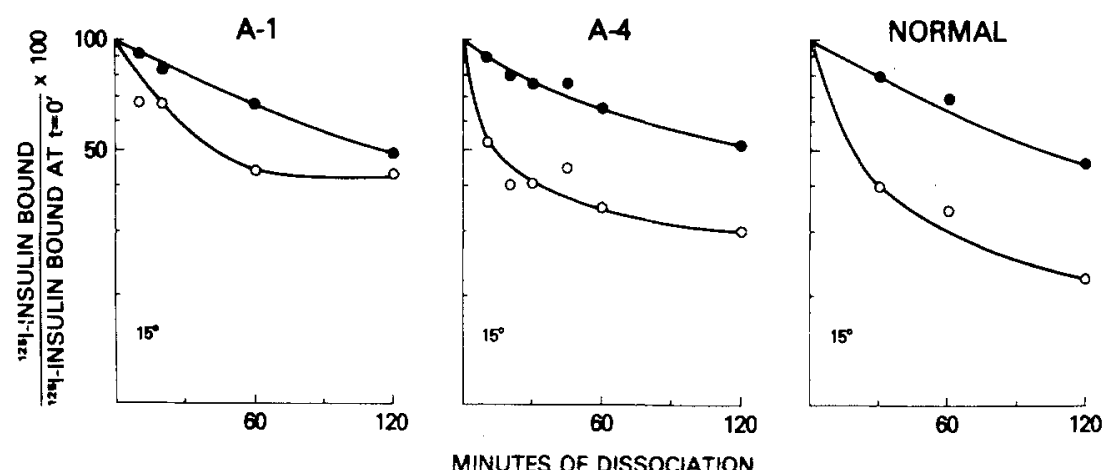

Fig. 2. Acceleration of the dissociation of receptor-bound ${ }^{125} \mathrm{I}$-insulin by unlabelled insulin in patients A-1, A-4 and a normal subject. Mononuclear cells were first incubated with $0.2 \mathrm{ng} / \mathrm{ml}$ of ${ }^{125} \mathrm{I}$-insulin for $180 \mathrm{~min}$ at $22^{\circ} \mathrm{C}$. Aliquots of $100 \mu \mathrm{l}$ were then diluted in either $10 \mathrm{ml}$ of buffer ("dilution only", closed circles) or buffer $+10^{-7} \mathrm{~mol} / \mathrm{l}$ insulin ("dilution + unlabelled insulin", open circles) for periods up to 120 minutes. At each time point assay tubes were centrifuged, the cell-associated radioactivity was counted and expressed as a percent of the receptor-bound ${ }^{125} \mathrm{I}$-insulin at time 0

${ }^{125} \mathrm{I}$-insulin bound

${ }^{125} \frac{\mathrm{I} \text {-insulin bound at } \mathrm{t}=0}{\mathrm{I}} \times 100$

Effect of Fasting on Type A Patients. Two patients, $\mathrm{A}-3$ and $\mathrm{A}-4$, were fasted for $72 \mathrm{~h}$ with monocyte binding studies performed at the beginning and end of the fast. In both cases, plasma insulin levels fell markedly (in patient A-3 $200 \mu \mathrm{U} / \mathrm{ml}$ to $10 \mu \mathrm{U} / \mathrm{ml}$ and $\mathrm{A}-4128 \mu \mathrm{U} / \mathrm{ml}$ to $30 \mu \mathrm{U} / \mathrm{ml}$ ); however, insulin binding was unchanged at the end of the fast (Fig. 3, left).

Effect of Antireceptor Antibodies. The effect of antireceptor antibodies (derived from type $B$ patients) on the binding of ${ }^{125} \mathrm{I}$-insulin to monocytes from patient A-4 is shown in Figure 4. Exposure of monocytes to
Type B sera inhibited subsequent ${ }^{125}$ I-insulin binding. The order of inhibitory potency of the three sera was identical to that observed with monocytes from normal subjects.

\section{Type B Patients}

Competition curves of insulin binding to monocytes of six patients with the Type B form of insulin resistance and acanthosis nigricans are shown in Figure 5. Each curve is abnormal in two respects. At the lowest concentrations of insulin $(0.2 \mathrm{ng} / \mathrm{ml})$ insulin binding 


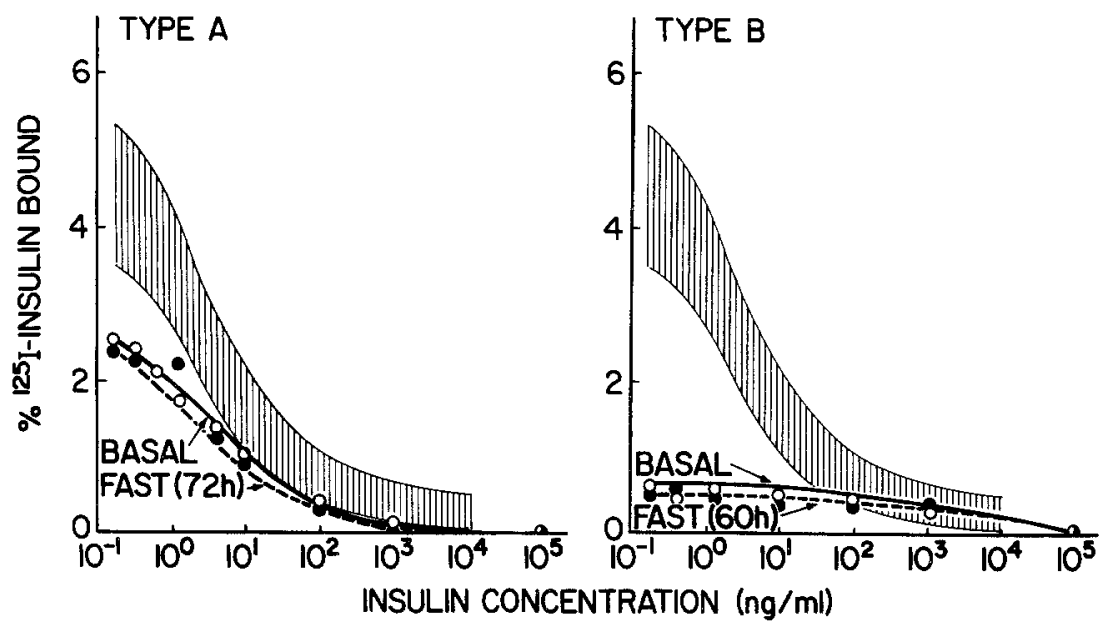

PATIENT A-4 MONOCYTES
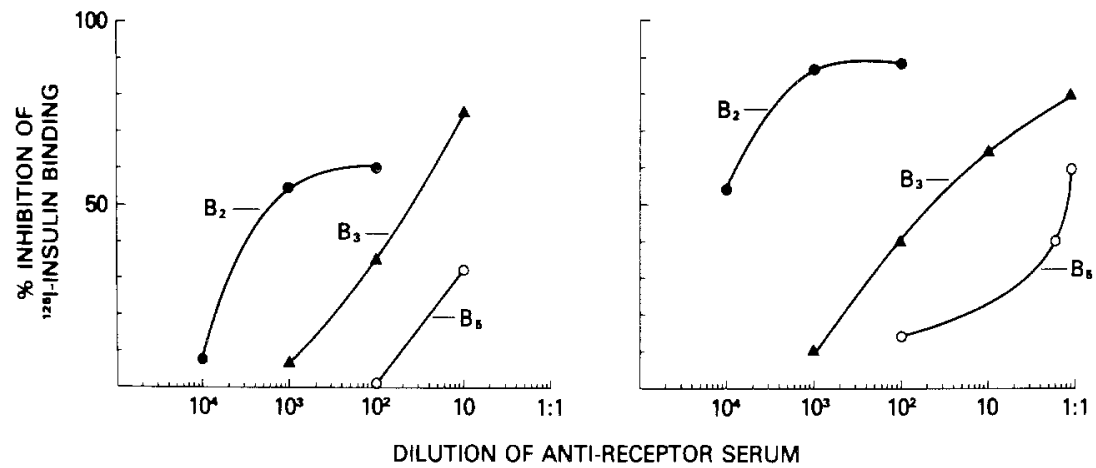

Fig. 3. The effect of fasting on insulin binding to monocytes of Type $A$ (A-4, left) and Type B (B-6, right) patients. For patient A4 , plasma glucose and insulin levels at 0 time, $24 \mathrm{~h}, 48 \mathrm{~h}$ and $72 \mathrm{~h}$ of the fast were $113,87,77$ and $70 \mathrm{mg} / \mathrm{dl}$ for glucose and $128,50,30$ and $30 \mu \mathrm{U} / \mathrm{ml}$ for insulin. For patient $\mathrm{B}-1$, plasma glucose and insulin levels at $0,16 \mathrm{~h}, 44 \mathrm{~h}$ and $60 \mathrm{~h}$ of the fast were $65,69,51,40 \mathrm{mg} / \mathrm{dl}$ and $112,38,<5$, $<5 \mu \mathrm{U} / \mathrm{ml}$, respectively

Fig 4. The effect of exposure to anti-receptor antibodies on ${ }^{125}$ I-insulin binding to monocytes from Type A patient and normal control. $B_{2}, B_{3}, B_{5}$ represent serum from patients $B-2, B-3$ and $B-5$

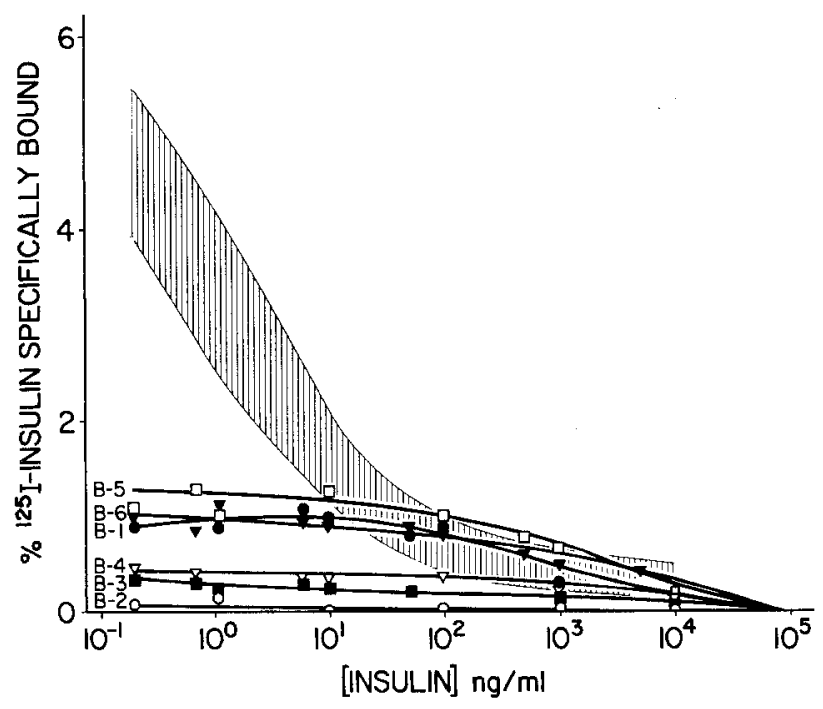

Fig. 5. Competition-inhibition curves of ${ }^{125} \mathrm{I}$-insulin binding to circulating monocytes of type B patients. All studies were done at the time of initial presentation when insulin resistance was most pronounced

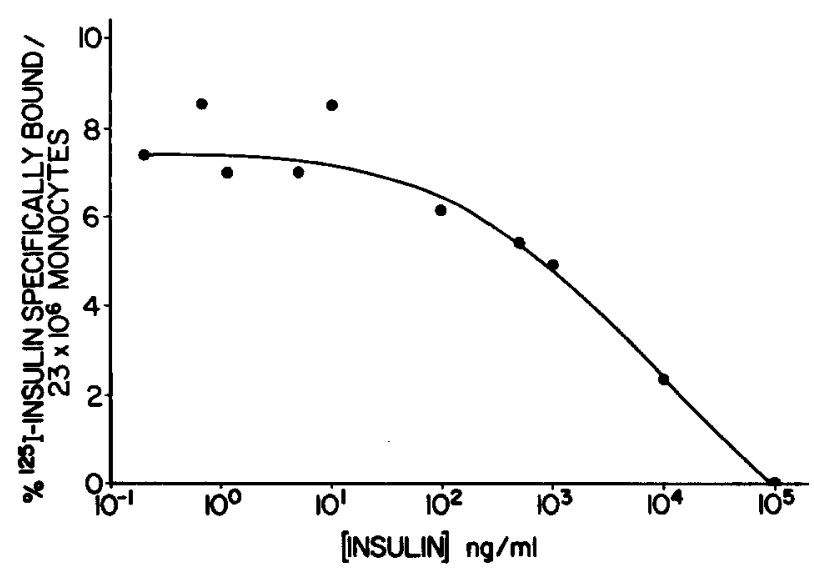

Fig. 6. Competition-inhibition curve of ${ }^{125} \mathrm{I}$-insulin binding in patient $\mathrm{B}-5$ when the concentration of monocytes in the assay was increased by 5.5 fold 

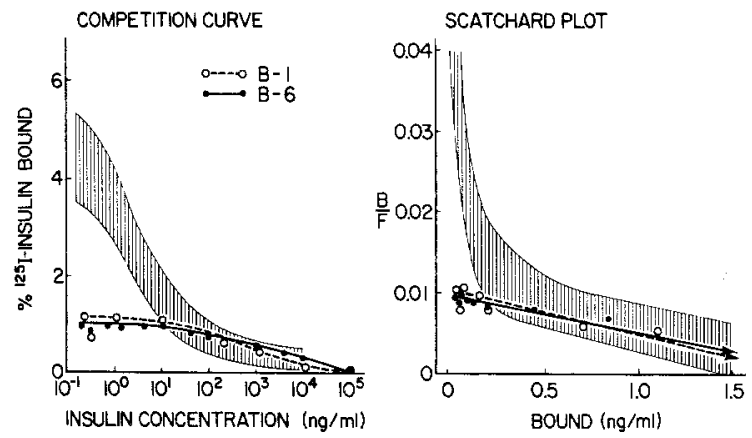

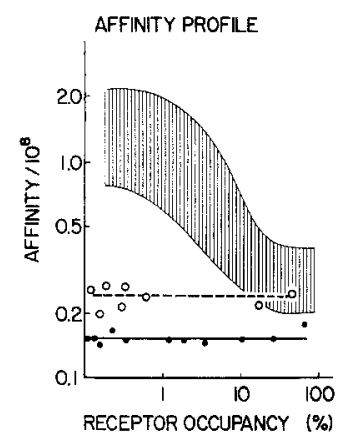

Fig. 7. Competition curves, Scatchard plots and affinity profiles of ${ }^{125} \mathrm{I}$-insulin to monocytes from patients B-1 and B-6 was only $5-25 \%$ of normal (mean). Second, the concentrations of insulin required to reduce maximal binding by $50 \%$ were markedly elevated. This latter finding was difficult to quantify in patients B-2 and B-3 since the specific binding of ${ }^{125} \mathrm{I}$-insulin was so low. However, in the other four patients (B-1, B-4, B-5 and B-6), some estimate could be obtained either by performing multiple binding studies or by increasing the concentration of cells (Fig. 6). In the Type B patients the amount of insulin required to decrease maximal binding by $50 \%$ ranged from 500 to $>1000 \mathrm{ng} / \mathrm{ml}$. By contrast, with monocytes from Type A and normal patients, the amounts of insulin needed to decrease maximal binding by $50 \%$ ranged from 1 to $12 \mathrm{ng} / \mathrm{ml}$.

To illustrate the quantitative analyses of the data for the Type B patients, studies for patients B-1 and B-6 are presented (Fig. 7). Scatchard plots and average affinity profiles of these data suggest that the receptors are present in normal or increased concentration but fixed in a lower affinity state (Fig. 7, right), thus accounting for the decreased binding of ${ }^{125}$ I-insulin at low insulin concentration, and the failure of competing insulin to appropriately decrease the maximal binding of ${ }^{125} \mathrm{I}$-insulin. Similar Scatchard plots and affinity profiles were observed in the other type $\mathrm{B}$ patients.

Cooperativity Experiments. The kinetics of dissociation, in the absence and presence of unlabeled insulin, were studied in three Type B patients (B-1, B-3, B-6). For patient B-3, all receptor-bound ${ }^{125}$ I-insulin dissociated in $10 \mathrm{~min}$ at $22^{\circ} \mathrm{C}$, even in the absence of unlabelled insulin. In patients B-1 and B- 6 , the dissociation rate of receptor-bound ${ }^{125} \mathrm{I}$-insulin was very rapid both in the presence and absence of $10^{-7} \mathrm{~mol} / 1$ insulin (Fig. 8). This contrasts with findings in type A patients and normal subjects in whom dissociation was slower with 1:100 dilution in the absence of insulin and markedly accelerated with insulin at $10^{-7} \mathrm{~mol} / \mathrm{l}$. The intrinsic rate of dissociation of

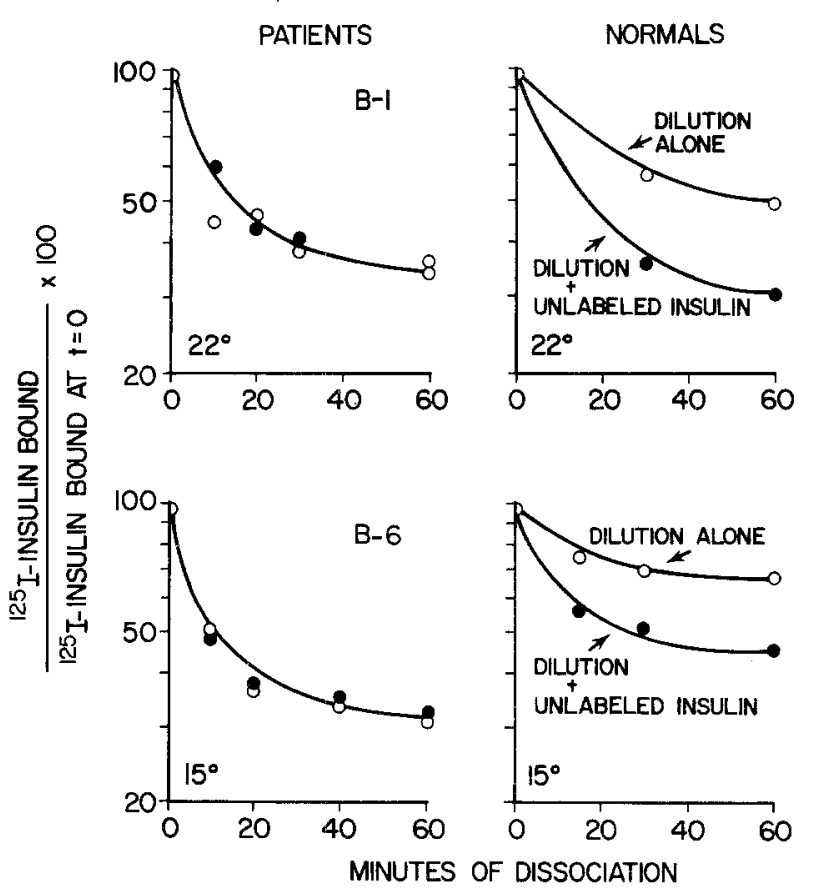

Fig. 8. Effect of unlabelled insulin on the dissociation rate of receptor-bound ${ }^{125} \mathrm{I}$-insulin to monocytes from patients $\mathrm{B}-1$ and B-6. Dissociation studies were performed at $22^{\circ} \mathrm{C}$ for patient B-1 and $15^{\circ} \mathrm{C}$ for patient $\mathrm{B}-6$. For comparison at the right, similar studies are shown for monocytes from normal controls

receptor-bound ${ }^{125}$ I-insulin ("dilution only") was increased in all 3 Type B patients with B-3>B-6> B-1.

Effect of Fasting. One Type B patient has been studied before and after a $60 \mathrm{~h}$ fast. After fasting, plasma insulin concentration fell from an initial $125 \mu \mathrm{U} / \mathrm{ml}$ to $<5 \mu \mathrm{U} / \mathrm{ml}$; however, insulin binding characteristics were unchanged from the initial studies (Fig. 3, right). 


\section{Discussion}

In this paper we have analyzed the basal, steady-state binding data of ${ }^{125} \mathrm{I}$-insulin to the circulating monocytes of patients with the Type A and Type B forms of insulin resistance and acanthosis nigricans. At the time of their initial presentation, when insulin resistance was most pronounced, both groups showed striking decreases in the binding of ${ }^{125} \mathrm{I}$-insulin to their circulating mononuclear cells. In Type A patients the predominant defect was a decrease in receptor concentration, whereas in the Type B patients a decrease in receptor affinity predominated. In addition, the kinetics of dissociation further indicated that different mechanisms account for the binding defects in the two patient groups.

The cause of the decrease in receptor concentration and the accompanying insulin resistance in the Type A patients is unknown. In addition to the Type A patients, there are several other conditions characterized by decreases in the concentration of insulin receptors on circulating cells. These include obesity [17, 25-31], functioning islet cell tumours (insulinoma) [32] and acromegaly [33]. In human and animal obesity, clinical insulin resistance is associated with a decreased concentration of insulin receptors, the magnitude of the receptor concentration decrease being proportional to basal levels of circulating insulin and the degree of insulin resistance. When obese patients are acutely fasted their plasma insulin levels fall and there is an increase in receptor affinity [17]. More prolonged food restriction produces an increase in receptor concentration toward the normal range [17]. In Type A patients, basal levels of plasma insulin were higher than in obese patients and the cellular concentrations of insulin receptors were proportionately decreased. In contrast to the obese patients, acute periods of fasting were not associated with any change in insulin binding despite decreased ambient levels of insulin, suggesting a primary receptor defect in the monocytes of the Type A patients.

The clinical characteristics of Type A patients can also be associated with other cellular defects [34-36]. We have evaluated a young woman with acanthosis nigricans, virilization and extreme insulin resistance. In contrast to the Type A patients, monocyte receptors for insulin were entirely normal, suggesting a postreceptor or intracellular defect $[34,35]$. Whether this latter patient represents a form fruste of the Type A patients, or alternatively, whether there are a spectrum of diseases with differing underlying mechanisms but similar clinical presentation is uncertain at the present time.
The relationship of acanthosis nigricans to insulin resistance is striking. All Type A patients had the dermatologic condition acanthosis nigricans at the time of initial presentation. Subsequently, one patient had complete and another partial remission of acanthosis nigricans associated with exogenous estrogen therapy; however, insulin resistance and the monocyte binding defect persisted. These findings suggest that the factors resulting in acanthosis nigricans are different from those accounting for the insulin resistance in the Type A patients.

The pathogenesis of the insulin resistance in the Type B patient is better understood. Several diverse lines of evidence implicate the anti-receptor autoantibodies as the major cause of the insulin resistance. First, exposure of normal human monocytes, rat adipocytes and lymphoblastoid cells to the receptor autoantibodies results in a binding defect that is characterized by a decrease in receptor affinity, similar to the defect found on patient monocytes $[8,10$, 37]. Second, in vitro procedures which elute surface immunoglobulins from the monocytes of Type B patients result in an increased binding of insulin and restore receptor affinity to normal [37]. In addition, we have recently performed multiple plasma exchanges in one Type B patient which resulted in progressive decreases in plasma levels of antireceptor antibodies and sequential increases in the affinity of monocyte receptors for insulin [14]. Third, in subsequent followup studies, several Type B patients have shown reversal of their insulin resistance $[5,6]$. This apparent increased sensitivity to insulin was accompanied by an increased binding of insulin to circulating monocytes and, often, alterations in the titre or character of the circulating autoantibodies $[5,6]$. Finally, long-term culture of fibroblasts and lymphocytes derived from the Type B patients demonstrated characteristics of insulin binding which were similar to cell cultures derived from normal individuals indicating that the binding defects do not represent a fixed component of all cells [37]. Taken together, these findings suggest that the insulin receptor in the Type B patients is normal.

The presence of "low affinity" receptors" in circulating monocytes is not unique to the Type B patients but has also been found in certain patients with ataxia telangiectasia $[38,39]$. These patients had insulin resistance and were found to have circulating 8S IgM immunoglobulins which inhibited binding to insulin receptors. Thus, circulating autoantibodies

\footnotetext{
1 The term "low affinity receptors" is extrapolated from the affinity profiles and refers to a flat affinity profile; this most likely reflects the reaction between insulin and the complexes formed by the insulin receptors and the anti-receptor antibodies
} 
against the insulin receptor are present in two distinct syndromes of insulin resistance (Type B patients and certain patients with ataxia telangiectasia) and result in characteristic binding defects on monocyte receptors for insulin. Although the total number of patients with autoantibodies to insulin receptors is small $(\sim 25)$, the prevalence of anti-receptor antibodies as a mechanism of insulin resistance remains to be determined. Recent methodological advances in the specificity and sensitivity of autoantibody assays and their future application to other insulin resistance states should help resolve this matter [13, $15]$.

Acknowledgements. The authors thank Maxine Lesniak, David Neville, Rolf Fussganger, Pierre De Meyts, Petros Thomopolous and Jeffrey Flier for their advice throughout these studies. This work was supported in part by grants from the Veterans Administration and the National Institutes of Health (AM-21250).

\section{References}

1. Field J B, Johnson B, Harring B (1961) Insulin-resistant diabetes associated with increased endogenous plasma insulin followed by complete remission. J Clin Invest 40:1672-1683

2. Flier J S, Kahn CR, Roth J, Bar R S (1975) Antibodies that impair insulin receptor binding in an unusual diabetic syndrome with severe insulin resistance. Science 190:63-65

3. Kahn C R, Flier J S, Bar RS, Archer J A, Gorden P, Martin MM, Roth J (1976) The syndromes of insulin resistance and acanthosis nigricans: insulin-receptor disorders in man. N Engl J Med 294:739-745

4. Blackard W G, Anderson J H, Mullinax F (1977) Anti-insulin receptor antibodies and diabetes. Ann Intern Med 86: 584-585

5. Bar R S, Flier J S, Jarrett D B, Gorden P (1977) Hypoglycemia and proliferation of low affinity insulin receptors in a patient with antireceptor antibodies. Diabetes 26:354

6. Flier J S, Bar R S, Muggeo M, Kahn C R, Roth J, Gorden P (1978) The evolving clinical course of patients with insulin receptor autoantibodies: Spontaneous remission or receptor proliferation with hypoglycemia. J Clin Endocrinol Metab 47:985-996

7. Flier J S, Kahn CR, Jarrett D B, Roth J (1976) Characterization of antibodies to the insulin receptors: A cause of insulinresistant diabetes in man. J Clin Invest 58:1442-1449

8. Flier J S, Kahn C R, Jarrett D B, Roth J (1977) Autoantibodies to the insulin receptor: Effect on the receptor interaction in IM-9 1ymphocytes. J Clin Invest 60:784-794

9. Jarrett D B, Roth J, Kahn CR, Flier J S (1976) Direct method for detection and characterization of cell surface receptors for insulin by means of ${ }^{125}$ I-labelled autoantibodies against the insulin receptor. Proc Natl Acad Sci USA 73:4115-4119

10. Kahn CR, Harrison LC (in press) Insulin receptor autoantibodies: Clinical and experimental studies. In: Randle P J, Steiner D F, Whelan W J (eds) Carbohydrate metabolism and its disorders, vol 3. Academic Press Inc. London

11. Kahn CR, Baird KL, Jarrett D B, Flier J S (1978) Direct demonstration that receptor crosslinking or aggregation is important in insulin action. Proc Natl Acad Sci USA 75: $4209-4213$

12. LeMarchand-Brustel Y, Gorden P, Flier JS, Kahn CR, Freychet P (1978) Anti-insulin receptor antibodies inhibit insulin binding and stimulate glucose metabolism in skeletal muscle. Diabetologia 14:311-318

13. Harrison LC, Flier J S, Roth J (1979) Immunoprecipitation of insulin receptor: A sensitive assay for receptor antibodies and a specific technic for receptor purification. J Clin Endocrinol Metab 48:59-65

14. Muggeo M, Flier J S, Abrams R A, Harrison L C, Deisserroth AB, Kahn CR (1979) Treatment by plasma exchange of a patient with autoantibodies to the insulin receptor. $\mathrm{N}$ Engl $\mathrm{J}$ Med 300:477-480

15. Harrison LC, Flier JS, Itin A, Kahn CR, Roth J (1979) Radioimmunoassay of the insulin receptor: A new role of receptor structure and function. Science 203:544-547

16. Pulini M, Raff S B, Chase R, Gorden EE (1976) Insulin resistance and acanthosis nigricans: Report of a case with antibodies to insulin receptors. Ann Intern Med 85:749-751

17. Bar R S, Gorden P, Roth J, Kahn CR, De Meyts P (1976) Fluctuations in the affinity and concentration of insulin receptors on circulating monocytes of obese patients: Effects of starvation, refeeding and dieting. J Clin Invest 58:1123-1135

18. Schwartz R H, Bianco A R, Handwerger B S, Kahn CR (1975) A demonstration that monocytes rather than lymphocytes are the insulin-binding cells in human peripheral blood mononuclear leukocyte preparations: Implications for studies of insulin-resistant states in man. Proc Natl Acad Sci USA 72: $474-478$

19. Hunter W M, Greenwood F C (1962) Preparation of iodine-131 labeled human growth hormone of high specific activity. Nature 194:495-596

20. Freychet P, Kahn CR, Roth J, Neville D M Jr (1972) Insulin interactions with liver plasma membranes. Independence of binding of the hormone and its degradation. J Biol Chem 247:3953-3961

21. Cline MJ, Lehrer RI (1968) Phagocytosis by human monocytes. Blood 32:423-435

22. Scatchard G (1949) The attractions of proteins for small molecules and ions. Ann NY Acad Sci 51:660-672

23. De Meyts P, Roth J (1975) Cooperativity in ligand binding: A new graphic analysis. Biochem Biophys Res Commun 68:1118-1126

24. De Meyts P, Bianco A R, Roth J (1976) Site-site interactions among insulin receptors: Characterization of the negative cooperativity. J Biol Chem 251:1877-1888

25. Marinetti GV, Shlatz L, Reilly K (1972) Hormone-membrane interactions. In: Fritz IB (ed) Insulin action: Proceedings of a Symposium on Insulin Action, held at Toronto, Canada, October 25-27, 1971. Academic Press, New York

26. Freychet P, Laudat MH, Laudat P, Rosselin G, Kahn CR, Gorden P, Roth J (1972) Impairment of insulin binding to the fat cell plasma membrane in the obese hyperglycemic mouse. FEBS Lett $25: 339-342$

27. Soll AH, Kahn CR, Neville DM Jr, Roth J (1975) Insulin receptor deficiency in genetic and acquired obesity. J Clin Invest $56: 769-780$

28. Archer J A, Gorden P, Roth J (1975) Defect in insulin binding to receptors in obese man: Amelioration with calorie restriction. J Clin Invest 55:166-174

29. Olefsky J M (1976) Insulin binding to adipocytes and circulating monocytes from obese patients. J Clin Invest 57: $1162-1165$

30. Harrison LC, Martin FIR, Melick RA (1976) Correlation between insulin receptor binding in isolated fat cells and insulin sensitivity in obese human subjects. J Clin Invest 58: 1435-1441

31. DeFronzo R, Soman V, Sherwin R, Hendler R, Felig P (1978) Insulin binding to monocytes and insulin action in human obesity, starvation and refeeding. J Clin Invest 62:204-213 
32. Bar R S, Gorden P, Roth J, Siebert C (1977) Insulin receptors in patients with insulinomas: Change in receptor affinity and concentration. J Clin Endocrinol Metab 44:1210-1213

33. Muggeo M, Bar R S, Roth J, Kahn CR, Gorden P (1979) The insulin resistance of acromegaly: Evidence for two alterations in the insulin receptor on circulating monocytes. J Clin Endocrinol Metab 48:17-25

34. Bar RS, Muggeo M, Roth J, Kahn CR, Havrankova J, Imperato-McGinley J (1978) Insulin resistance, acanthosis nigricans and normal insulin receptors in a young woman: Evidence for a postreceptor defect. J Clin Endocrinol Metab $47: 620-625$

35. Imperato-McGinley J, Peterson RE, Sturla E, Dawood Y, Bar R S (1978) Primary amenorrhea associated with hirsutism, acanthosis nigricans, dermoid cysts of the ovaries and a new type of insulin resistance. Am J Med 65:389-395

36. Kobayashi M, Olefsky J M, Elders J, Mako ME, Given B D, Schedwie HK, Fiser R H, Hintz R L, Horner J A, Rubenstein AH (1978) Insulin resistance due to a defect distal to the insulin receptor: Demonstration in a patient with leprechaunism. Proc Natl Acad Sci USA 75:3469-3473
37. Muggeo M, Kahn CR, Bar R S, Rechler MM, Flier J S, Roth J (1979) The underlying insulin receptor in patients with antireceptor autoantibodies: Demonstration of normal binding and immunologic properties. J Clin Endocrinol Metab 48: 110-119

38. Bar RS, Levis WR, Rechler MM, Harrison LC, Siebert C, Podskalny J, Roth J, Muggeo M (1978) Extreme insulin resistance in ataxia telangiectasia: Defect in affinity of insulin receptors. N Engl J Med 298:1164-1171

39. Harrison LC, Muggeo M, Bar RS, Flier JS, Waldmann T, Roth J (1979) Insulin binding defects induced by a serum globulin factor in ataxia telangiectasia. Clin Res 27:252A

Received: May 30, 1979,

and in revised form: December 10, 1979

Dr. R. S. Bar

3E-50

V. A. Medical Center

Iowa City, IA 52240

USA 